\title{
The Science-Math Stories Based on Digital Learning: Digital Literacy Innovation in Increasing Ability to Solve Problems
}

\author{
https://doi.org/10.3991/ijet.v16i09.22039 \\ Muhammad Nur Wangid ( $\left.{ }^{凶}\right)$, Chandra Adhi Putra \\ Yogyakarta State University, Yogyakarta, Indonesia \\ m_nurwangideuny.ac.id \\ Hendra Erik Rudyanto \\ Universitas PGRI Madiun, Kota Madium, Indonesia
}

\begin{abstract}
The existence and use of technology can be a means of maximizing the potential of students' thinking abilities, including the ability to solve problems. Learning that utilizes cellular technology that contains material in science-math stories becomes one of the ways of utilizing technological developments in learning activities. The study used a pretest-posttest control group design with more than one experimental group. There were two experimental groups from two schools that experienced learning with science-math stories based on digital learning as digital literacy media, and one control group from another school who carried out literacy activities using reading books in the class and the library. The use of science-math stories based on digital learning as a digital literacy media can improve problem-solving skills for elementary school students. The main content in the form of realistic fiction illustrated stories with adventure themes that raise environmental problems to be solved becomes the main strategy in improving the ability to solve the problems of elementary school students.
\end{abstract}

Keywords - Science-math stories, digital learning, elementary school students, problem-solving skills

\section{Introduction}

Advances in technology and information in the globalization era need to be balanced with the development of all matters relating to education as an effort to improve the intelligence of the nation's next generations. The most important role of education is to prepare the laborers in the future and the community to face challenges at that time [1],[2]. Only people with renewal can compete. Speigel [3] said that when faced with global competition and access to information and technology-based, there will always be a need for self-renewal. National education also implies the development of various aspects, especially the ability to think as a provision in the future. Guiding and 
directing the younger generation to be smart is also one of the main goals of education [4].

Educational programs by applying HOTS have resulted in benefits on national standardized tests, on metacognitive measures, in problem-solving, and even in average grade points [5]. The ability to solve problems refers to the skills possessed by someone to apply previously acquired knowledge to a new one in an unknown situation. Solving problems is a real effort by using the knowledge, skills, and understanding possessed to find solutions to a problem at hand [6]. For elementary school students, the ability to solve problems is used to find solutions to new problems in the school environment and community environment based on experience through appropriate strategies [7], [8]. Processes that involve the ability to solve problems become key processes in learning activities that are done by the students, especially in the realm of science and mathematics [9]. Elementary school students with good problem-solving skills will be able to develop concepts early so they can carry out tasks and develop skills even though they have not been taught [10].

The urgency of problem-solving skills can be fulfilled by making innovations related to the delivery of education. This can be done in several ways but one of them can be done through the application of media to support learning activities. Supporting media in learning activities are all things that are used during the teaching and learning process in communicating learning resources inside and outside the classroom [11], [12]. The use of supporting media in the learning activities is one way to increase the ability to develop students' potential in the global era with all technological developments.

Characteristics of elementary school students' thinking abilities are different from adults. According to Piaget [13], the age of the elementary school students ranging from 7 to 11 years is at the stage of concrete operational thinking abilities. The thinking process at this stage involves the use of logical reasoning stages replacing intuitive reasoning, but only in concrete situations. They have the skills to do the classification but have not been able to solve abstract problems. At this stage, students need media that have concrete interesting content. One technological device that can be used as a learning medium to meet the needs and according to these considerations is cellular technology.

Learning media that utilize cellular technology with the concept of cellular learning or digital learning enables students to make dynamic, visual representations of the situation they faced [14]. The use of technology in learning can improve students' mathematical abilities [15], [16]. Also, both students and teachers are currently able to operate and even have personal cellular technology devices. So it can be assumed that it is easier for teachers to utilize digital devices to support learning for students. An important part of digital learning is that learners are digital and are not limited to specific locations [17]. In making use of supporting media in learning activities based on digital learning, media designers must consider various characteristics of mobile devices and cellular learners to design good media [18],[19]. Thus, it can be interpreted that cellular technology is a supporting medium that has the potential to be utilized in learning and is easily adapted and made according to the characteristics of students. 
Digital learning-based media is developed as interactive multimedia that combines several types of media into a more attractive whole with diverse content. As delivered by previous research that multimedia is a series of diverse media in the concept of appearance or program of learning independently [20]. Multimedia is supported by interactive concepts that also involve and enhance their interest in learning in a student-centered environment [21].

Stories that contain science-math material or science-math stories can be a way of delivering material according to the characteristics of elementary school students to improve their problem-solving skills. Stories for elementary school students should be designed with an environment that will help students to think at a higher level [22]. Stories can also help develop imagination and gain satisfying new experiences [23]. This new experience is the basis for students in improving their problem-solving skills.

\section{$2 \quad$ Literature Review}

The concept of science-math is realized through the display of the material in the form of realistic fictional adventure stories that raise environmental problems. A children's fairytale presentation with scientific content entitled "Prince Nara and Time Traveler". Through interactive dialogue and role models, characters or characters can provide examples in the problem-solving process. In a learning medium in the form of stories, characters and characterizations provide a model picture for students. Figures are the characters/actors in the story [24]. Meanwhile, characterizations of the picture of people who play a specific role include habits and properties possessed [25]. The figure in this science-math story is a human child who plays an environmental hero. This is because the age of the elementary school students more easily interacts with pictorial stories if the characters or the figures are humans, not animals [26]. The figures and the characters in the story are all good. This is because the supporting developed media in the learning activities will be used by students independently. So the developer anticipates students imitating the bad characters or behaviors of the characters because of the meaning of the story. The characters in this story include Prince Nara, Aldino, Raja Maheswara, Professor Afro, Almira, and environmental fighters as supporting characters. The characters are adjusted to the characteristics of 4th-grade elementary school students, namely two-dimensional cartoon characters with anime types to make them look more realistic. The science-math story consists of 3 parts containing science and 2 parts containing mathematics which can be accessed via 5 link buttons on the table of contents view as shown Figure 1 below. 


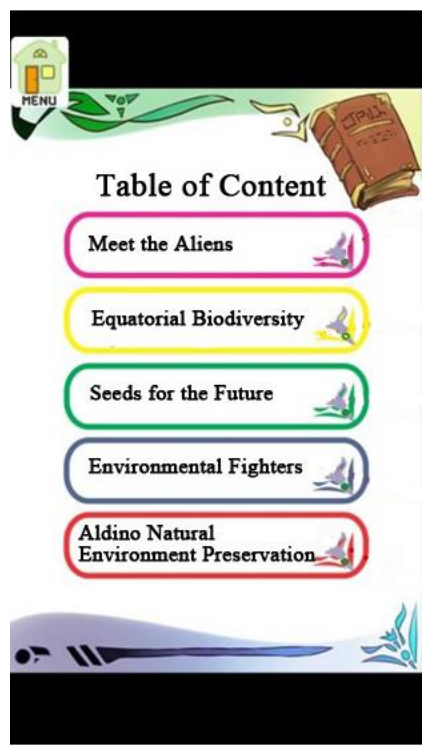

Fig. 1. Initial display of Digital Learning-Based on Science-Math

Parts of the story contain science-math material and direct students to solve problems in each part of the story before proceeding to the next section. The first part of the story titled "Meet the Aliens" tells the story of Prince Nara rescuing aliens who turned out to be humans from the future. This section contains material on science about the factors that cause environmental damage. The second part titled "Equatorial Biodiversity " tells the story of prince Nara who shows the diversity of natural wealth belonging to the Equator State to his best friend Aldino from the future. This section contains material on science about the parts of plants and their usefulness in preserving nature. The third section entitled "Seeds for the Future" tells the story of Aldino's efforts in preparing seeds to be brought into the future to tackle environmental pollution. This section contains material on mathematical content about the least common multiple. The fourth section entitled "Environmental Fighters" tells about Aldino's efforts to gather people who care about the environment around him. This section contains mathematical content material about the smallest common factor. The last section titled "Aldino Natural Environmental Preservation" tells the results of Aldino's efforts to save the environment from environmental damage. This last part concludes the results of the collaboration and efforts made in overcoming the damage to the natural environment. In each part of the story, there is a "Do you know?" which contains a summary of learning material according to the needs of students in improving their competence. Improving the ability to solve problems in students is directed through the illustration of problems in the story as well as various alternative solutions to problem-solving based on theories learned in the application.

Science-math stories and other supporting contents are made in the form of application software with the ".apk" format titled "Citraloka Adventure" which can be used on Android type mobile devices. The use of digital technology is considered as saving 
money, saving time, and providing useful information so that it impacts people's habits or way of life [27]. The development of cellular technology in people's lives has the potential for new teaching and learning patterns [18]. The science-math story was developed based on several aspects of digital learning, namely 1) the simplicity of the application packaging, 2) the suitability of the display screen, 3) direct feedback, 4) the availability of features and functions, 5) the use of icons and guides, 6) segmentation, 7) age and user experience suitability, 8) direct manipulation, and 9) user interface metaphor [28].

Science-math learning based on digital learning, in general, can be interpreted as a story developed by giving students facilities to actively learn that emphasize knowledge and process skills by applying elements of digital learning. The concept of learning through science stories based on digital learning is an independent literacy learning concept. Especially elementary school students in the fourth grade of 9-12year-old have physical and mental skills and abilities that have developed rapidly. The age range makes it possible to receive a variety of interesting literature to improve their abilities, including the ability to solve problems [24],[29]. The application of science-math stories based on digital learning is done by considering the production, circulation, and acceptance of meaning to maximize the functioning of the media in general [30], [31]. Thus, science-math learning stories based on digital learning can support efforts to improve the ability to solve problems in fourth-grade students at the elementary school level if implemented optimally through literacy activities.

\section{$3 \quad$ Methods}

The study was conducted using a pretest-posttest control group design technique with more than one experimental group developed by Johnson and Christenses [32]. Researchers used two experimental groups and one control group. There were two experimental classes, each group consisting of 30 students and 23 students. Meanwhile, in the control class, there were 26 students. The following class characteristics were used as the research study. The study involved 79 the fourth-grade elementary school students in Yogyakarta as research subjects. School selection was based on certain criteria, namely: having an A accreditation, implementing a school literacy program, and having digital equipment facilities to support learning activities. Determination of the sample used as research subjects were using simple random sampling technique with the assumption that all fourth classes in schools with the same characteristics have the same opportunity to be selected as research subjects [33]. The following are the characteristics of the class groups selected as subjects of science learning based on digital learning. 
Table 1. The Characteristics of the Experiment and Control Classes

\begin{tabular}{|c|c|c|c|c|c|c|c|c|c|}
\hline \multirow{3}{*}{ Type of Classes } & \multicolumn{8}{|c|}{ Ages (Years) } & \multirow{3}{*}{ Total } \\
\hline & \multicolumn{2}{|c|}{9} & \multicolumn{2}{|c|}{10} & \multicolumn{2}{|c|}{11} & \multicolumn{2}{|c|}{12} & \\
\hline & $M$ & $F$ & $M$ & $F$ & $M$ & $F$ & $M$ & $F$ & \\
\hline Experiment 1 & 1 & 2 & 7 & 10 & 5 & 4 & 1 & - & 30 \\
\hline Experiment 2 & - & - & 9 & 6 & 2 & 3 & 2 & 1 & 23 \\
\hline Control & - & 3 & 9 & 7 & 2 & 5 & - & - & 26 \\
\hline Total & 1 & 5 & 25 & 23 & 9 & 12 & 3 & 1 & 79 \\
\hline
\end{tabular}

Literacy activities in the experimental group used supporting media based on digital learning science-math stories. Meanwhile, the control group carried out literacy activities using reading books in the classroom or the library without using sciencemath learning stories based on digital learning. The three classes together carried out pretest activities carried out before treatment and posttests carried out after receiving treatment related to the measurement of problem-solving skills. Pretest and posttest are in the form of a written type of limited response test items. This test is proposed to limit the content of answers and forms of students' written responses [34]. This test is intended to provide student direction and facilitate scoring. This written test is used to measure the ability to solve problems before and after the literacy process takes place using science learning based on digital learning. The limits used in the test lead to indicators of problem-solving ability.

The instrument used in the measurement of the ability to solve problems in the form of items in the test sheet the ability to solve problems in the form of description. The questions consist of two questions about the science-math that are examined with the stages of problem-solving in each problem [13], [34], [35]. The instrument is a series of synthesis type questions that require students to mix points from the material being studied and then form it in a new form or new pattern [36]. The following description is the scoring criteria by indicators of the ability to solve problems in science and Mathematics content.

Table 2. The Indicators of the Ability to Solve Science and Mathematics Content Problems

\begin{tabular}{|l|l|l|c|}
\hline \multirow{2}{*}{ Indicators } & \multicolumn{1}{|c|}{ Scoring Descriptions } & Score \\
\cline { 2 - 4 } & \multicolumn{1}{|c|}{ Science Content } & \multicolumn{1}{c|}{ Mathematics Content } & 10 \\
\hline $\begin{array}{l}\text { Formulate the prob- } \\
\text { lems }\end{array}$ & $\begin{array}{l}\text { Describing the various conse- } \\
\text { quences that are relevant to the } \\
\text { problem }\end{array}$ & $\begin{array}{l}\text { Writing down the numbers that will be } \\
\text { calculated after analyzing the problem } \\
\text { in the story }\end{array}$ & 10 \\
\hline $\begin{array}{l}\text { Developing the } \\
\text { strategies in prob- } \\
\text { lem-solving }\end{array}$ & $\begin{array}{l}\text { Describing information that is } \\
\text { known to produce an appropriate } \\
\text { solution }\end{array}$ & $\begin{array}{l}\text { Calculating and searching for prob- } \\
\text { lems solving strategies correctly }\end{array}$ & 10 \\
\hline $\begin{array}{l}\text { Exploring possible } \\
\text { strategies }\end{array}$ & $\begin{array}{l}\text { Writing down the reasons and } \\
\text { linking the solutions with the } \\
\text { materials being studied }\end{array}$ & $\begin{array}{l}\text { Determining the correct calculation } \\
\text { methods along with the reason and its } \\
\text { solution }\end{array}$ & 15 \\
\hline $\begin{array}{l}\text { Evaluating the effect } \\
\text { of the problem } \\
\text { solution }\end{array}$ & $\begin{array}{l}\text { Making conclusions based on } \\
\text { accompanied by appropriate } \\
\text { theories or effects }\end{array}$ & $\begin{array}{l}\text { Writing the conclusions about the } \\
\text { solution to the problem based on the } \\
\text { results of the count. }\end{array}$ & 15 \\
\hline
\end{tabular}


Data to determine the effectiveness of the product obtained from the results of the assessment of the ability to solve the problem then analyzed using t-tests. The increase in each dependent variable can be determined by independent sample t-test and paired sample t-test. An independent sample t-test was conducted to determine differences in the ability to solve problems in the experimental class with the control class. Meanwhile, paired sample t-tests were conducted to determine differences in problem-solving abilities and character responsibilities in the experimental class before and after literacy activities were carried out using digital learning based on the science-math stories.

\section{$4 \quad$ Results and Discussion}

\subsection{Data collection and analytical work}

To find out the difference in the ability to solve problems in students who are literacy activities using science-math learning stories based on digital learning with students who do not use an independent t-test using posttest data. The following is a recap of the results of the independent t-test calculation of the results of the posttest problem-solving ability.

Table 3. Recap of Independent T-Test Results Posttest Results Ability to Solve Problems.

\begin{tabular}{|l|l|c|c|}
\hline \multicolumn{1}{|c|}{ Type of Classes } & \multicolumn{1}{|c|}{ Conditions } & Significance level & P \\
\hline Experiment 1 & Posttest & 0,000 & 0,05 \\
\hline Control & Posttest & 0,000 & 0,05 \\
\hline Experiment 2 & Posttest & 0,000 \\
\hline Control & Posttest & \multirow{2}{*}{0.0} \\
\hline
\end{tabular}

Based on the table, the calculation of the independent t-test ability to solve problems in the experimental class 1 with the control class and experimental class 2 with the control class showed a significance value $<0.05$, which is 0.000 . Thus, it can be concluded that there are differences in the ability to solve problems between students who take literacy activities using science learning stories based on digital learning and students who do not use science stories based on digital learning.

Next, a paired t-test analysis was performed to determine differences in the ability to solve problems in the experimental class before and after the literacy activities were carried out using science learning based on digital learning. The following is a recap of the results of the paired t-test calculation of the ability to solve problems.

Table 4. Recap of Paired t-test Results Ability to Solve Problems.

\begin{tabular}{|c|c|c|c|}
\hline Type of Classes & Conditions & Significance level & $\mathbf{P}$ \\
\hline Experiment 1 & Pretest & \multirow{2}{*}{0,000} & \multirow{2}{*}{0,05} \\
\hline Experiment 1 & Posttest & & \\
\hline Experiment 2 & Pretest & \multirow{2}{*}{0,000} & \multirow{2}{*}{0,05} \\
\hline Experiment 2 & Posttest & & \\
\hline
\end{tabular}


Based on the table, the paired t-test calculation of problem-solving ability in the two classes of experimental conditions pretest and posttest showed a significance value $<0.05$, which is 0.000 . Thus, the results can be drawn that there are differences in the ability to solve problems in students before and after participating in literacy activities using science-math based on stories based using digital learning.

\subsection{Discussion of findings}

The result of the study showed that the whole activities, content, and features of the science-math stories based on digital learning directly to the improvement of problem-solving stages, namely 1) formulating the problem, 2) developing a problemsolving strategy, 3) exploring possible strategies, and 4) evaluate the effect or effects of problem solutions. The storyline and the examples of how the characters solve the problems encountered in the story are the main factors causing an increase in the ability to solve problems.

The construction of science-math learning will involve students in various skills upgrades. The science process skills for elementary school level include skills in observing, classifying, measuring, communicating, predicting, and inferring [37]. Meanwhile, basic math skills lead to students' ability to connect mathematics with various disciplines, think critically about the content, and communicate key components of mathematical concepts [38]. Mathematical basic abilities also become the basis for students to build good procedural abilities to solve mathematical and contextual problems [39]. Mathematical basic abilities also become the basis for students to build good procedural abilities to solve mathematical and contextual problems

The science-math learning based on digital learning provides learning experiences for students in addition to conventional learning conducted by teachers in the classroom. The media also includes material and enrichment questions that are appropriate to learn in school and can be studied again to support student literacy activities. The concept of digital learning makes it possible for students to record their reflections on something through text, images, and audio, the product developed also contains text content in the form of stories along with material summaries, illustrated images in the form of two-dimensional cartoons, and theme songs and accompanying music as supporting media audio content [40]. Digital learning has the potential to facilitate and enhance collaboration between students to access, discover, discuss, share environmental concerns through features in it and argue about environmental issues [41]. The media was developed in the form of a native app that is an application created and compiled with a programming language to run specifically on a particular OS, in this study the Android OS [42].

The science-math stories based on digital learning are created with complex varied contents that include various activities that enhance problem-solving skills. As stated by Zheng \& Zhou (2006) that media that can be used as a support in improving problem-solving skills is also complex to contain all the competencies required by students. Critical thinking often involves the ability to interpret information and make decisions in the form of solutions based on that information [44]. Thus, it can be interpreted how to conduct a learning environment that is conducive to improving the 
ability to solve problems by providing information to students to be studied in the process of finding a solution. Elementary school students can solve a little complex problem as long as the problem is concrete and not abstract [45]. Thus, it can be interpreted how to conduct a learning environment that is conducive to improving the ability to solve problems by providing information to students to be studied in the process of finding a solution. Elementary school students can solve a little complex problem as long as the problem is concrete and not abstract [46]. Thus, it can be interpreted how to conduct a learning environment that is conducive to improving the ability to solve problems by providing information to students to be studied in the process of finding a solution. Elementary school students can solve a little complex problem as long as the problem is concrete and not abstract.

The main content is in the form of adventure stories that raise environmental problems to train students to improve their problem-solving skills. An adventure story is one type of realistic fiction to raise something that becomes a problematic community life. This type of story is being loved by 10 -year-old children and can help to develop imaginations and gain satisfying new experiences [23]. The figure in this sciencemath story is a human child who plays an environmental hero. This is because elementary school-age students more easily interact with pictorial stories if the figures or characters are humans, not animals [26]. Science-math stories with adventure themes and child characters as heroes in the adventure are characteristics that can enhance problem-solving abilities. As stated by previous study that one way to provide learning that can improve students' abilities is to use stories [47].

By learning about environmental problems, students can consider choices, identify alternatives, communicate, and ask the best questions, analyze inputs, and make decisions in the future [48]. These abilities support students in carrying out the stages of solving problems. The ability to solve problems becomes one of the key competencies developed in this media because students need to deal with changes, uncertainties, and phenomena that exist in the world [49]. For the students, the ability to solve problems is used to find solutions to problems that occur in the school environment and community environment based on the experience they have [7]. By increasing the ability to solve problems through this media, students can meet their needs in improving their competencies, especially in the field of science-math, because science-math materials are based on circumstances, events, and phenomena that occur in nature.

This media becomes an interactive support media that can be used independently containing illustrated stories about realistic fictional adventures about environmental problems supported by theme songs and story accompaniment music as well as quizzes or exercises in problem-solving. Through a series of stories supported by practice questions or quizzes, students are given examples and directions in solving problems. Conditioning the imagination process in the age of elementary school students when they are reading science-math stories is supported by illustrated images. Stories with illustrated pictures or commonly referred to picture stories are created by combining text with illustrations in clarifying and conveying story content to students [24], [25], [50]. The emergence of picture illustrations in picture storybooks is to provide an extension of the meaning of the storyline and the images used are usually flat or fixed [51]. Thus, two-dimensional cartoon images are considered to be appropriate illustra- 
tions in science-math stories. The ability of cartoons is very large to attract attention, affect the attitudes and behavior of someone [52].

Science-math stories based on digital learning make science-math stories with the help of two-dimensional illustrated images become the main content. With a series of words in the story, the material is presented in verbal form. Meanwhile, using pictures, the material is presented in the form of images [53]. But as multimedia, this media also unites other supporting content besides the main content. Assisted by children's songs as theme songs, musical accompaniment of stories, problem-solving exercises, and material learning, science-math media stories can be used as intermediaries by the stages of development of the age of the elementary school students. The songs related to material and musical accompaniment can provide effectiveness in learning, thinking, and remembering skills, therapeutic effects such as awareness and self-expression, and aesthetics [54].

The next appropriate supporting content is the tasks/questions of reasoning and quizzes. As stated by previous research that learning activities based on digital learning generally consist of learning resource components and activities which include accessing information, supporting information, and evaluating [55]. Through assignments /questions and quizzes on the developed media, students are expected to be able to carry out learning activities independently. These assignments/questions help teachers apply learning activities outside the classroom using digital learning-based media [56].

However, the efforts to improve problem-solving for students do not only through the media of science-math stories based on digital learning. Teachers and parents need to be involved to provide experiences that develop children's curiosity and thinking patterns in solving problems. Enhancing problem-solving ability that is caused by this media has not been able to fully form new habits on the students' level in elementary school. The ability to solve problems requires time to develop optimally, but quantitatively the results of tests that show improved results have demonstrated the effectiveness of digital learning-based media as well as research conducted by Yang [57]. Also, limited time makes the basic abilities and environment that students have not been able to optimally form new habits for students to solve problems. The goal of problem-solving ability is not to form new habits, but rather to develop approaches to think and handle challenging situations [58]. Also, limited time makes the basic abilities and environment that students have not been able to optimally form new habits for students to solve problems. The goal of problem-solving ability is not to form new habits, but rather to develop approaches to think and handle challenging situations.

\section{Conclusion}

The science-math stories based on digital learning are effectively used in literacy activities to improve the ability to solve the problem of the fourth-grade students in state elementary schools in Yogyakarta, based on experimental results through effectiveness testing through independent t-test analysis, and paired t-test. Efforts to improve the ability to solve problems effectively can be done by applying science-math 
stories based on digital learning in literacy activities for elementary school students. Digital literacy media in the form of applications with content in the form of realistic fictional adventure stories, two-dimensional cartoon illustrations, summaries of the material contents in science-math, theme songs, and storytelling music support become one of the strategies in improving problem-solving skills in elementary school students. The representation of the problem in the stories as well as the explanation of various alternative solutions based on the material learned in the application helps students improve their abilities. Utilization of science-math stories based on digital learning should be done according to the direction of the teacher in collaboration with parents to maximize their use in student literacy activities.

\section{References}

[1] B. Trilling and C. Fadel, 21 st centruy skills - learning for life in our times. San Francisco: Jossey-Bass, 2009.

[2] H. E. Rudyanto, Marsigit, M. N. Wangid, and S. Gembong, "The use of bring your own device-based learning to measure student algebraic thinking ability," Int. J. Emerg. Technol. Learn., vol. 14, no. 23, pp. 233-241, 2019. https://doi.org/10.3991/ijet.v14 $\underline{\mathrm{i} 23.11050}$

[3] D. Hopkins, The Practice And Theory of School Improvement International Handbook of Educational Change. Nethrlands: Springer, 2005.

[4] T. Lickona, Educating for characte: How our school can teach respect and responsibility. New York: Bantam Books, 1992. https://doi.org/10.1177/019263659207654519

[5] S. M. Brookhart, How to assess higher-order thinking skills in your classroom. Alexandria, VA: ASCD.

[6] S. Krulik and J. A. Rudnick, The new sourcebook for teaching reasoning and problem solving in elementary school, Illustrate. Boston: Allyn and Bacon, 1995.

[7] A. Muzanni and Muhyadi, "Pengembangan perangkat pembelajaran problem solving mata pelajaran IPA terhadap hasil belajar kognitif siswa SD," J. Prima Edukasia, vol. 6, no. 2, pp. 166-176, 2018. https://doi.org/10.21831/jpe.v4i1.7746

[8] M. Gredler, Learning and instruction: Theory into practice, 6th ed., no. 814. New Jersey: Pearson, 2008.

[9] D. H. Schunk, Learning theories: An educational perspective, 6th ed. Boston: Pearson, 2012.

[10] D. A. Grouws and K. J. Cebulla, "Improving student achievement in mathematics, part 1: research findings," ERIC Clear. Sci. Math. Environ. Educ., vol. 7469, no. 217, pp. 1-7, 2000.

[11] R. Heinich, M. Molenda, J. D. Russell, and S. E. Smaldino, Instructional media and technologies for learning, 7th ed. New Jersey: Prentice Hall, 2002.

[12] S. E. Smaldino, D. L. Lowther, C. Mims, and J. D. Russell, Instructional media and technology for learning, 12th ed. New York: Pearson Education, Inc. All, 2019.

[13] J. W. Santrock, Educational Psychology: theory and application to fitness and performance, 6th ed. New York: McGraw-Hill Education, 2018.

[14] N. Calder, K. Larkin, and N. Sinclair, Using mobile technologies in the teaching and learning of mathematics. Canada: Springer, 2018.

[15] H. E. Rudyanto, A. Ghufron, Hartono, and S. Gembong, "Multimedia flash mathematics with cultural perspective (ethnomathematics) to develop elementary school students' 
creative thinking," J. Adv. Res. Dyn. Control Syst., vol. 6, no. Special Issue, pp. 1714$1720,2018$.

[16] M. F. Amir, C. Chotimah, R. Afandi, H. E. Rudyanto, and I. Anshori, "Design Research Study: Investigation of Increasing Elementary Student' s Spatial Ability Using 3Dmetric," J. Adv. Res. Dyn. Control Syst., vol. 10, no. 6, pp. 1707-1713, 2018. https://doi.org/10.31227/osf.io/6fbzj

[17] C. Udell and G. Woodill, Mastering mobile learning: Tips and techniques for success. New Jersey: John Wiley \& Sons, Inc, 2015.

[18] Y. A. Zhang, Handbook of mobile teaching and learning. 2015.

[19] S. I. Malik, M. Al-Emran, R. Mathew, R. M. Tawafak, and G. AlFarsi, "Comparison of ELearning, M-Learning and Game-based Learning in Programming Education," Int. J. Emerg. Technol. Learn., vol. 15, no. 15, pp. 133-146, 2020. https://doi.org/10.3991/ ijet.v15i15.14503

[20] I. Deliyannis, Interactive Multimedia, First. Croatia: InTech, 2012.

[21] M. F.-T. Leow and M. Neo, "Interactive Multimedia Learning: Innovating Classroom Education in a Malaysian University," Turkish Online J. Educ. Technol., vol. 13, no. 2, pp. 99-110, 2014.

[22] M. S. B. Ozsezer and H. B. Canbazoglu, "Picture in children's story books : Children's perspective," Int. J. Educ. Methodol., vol. 4, no. 4, pp. 103-115, 2018.

[23] B. Nurgiyantoro, Sastra Anak: Pengantar Pemahaman Dunia Anak. Yogyakarta: UGM Press, 2013.

[24] C. L. Brown and C. M. Tomlinson, Essentials of children's literature, 3rd ed. New York: Allyn \& Bacon A Viacom Company, 1999.

[25] D. Mitchell, Children's literature: An invitation to the world. Boston: Allyn and Bacon, 2002.

[26] M. Zohrabi, L. Dobakhti, and E. M. Pour, "Interpersonal meanings in children's storybooks," Iran. J. Lang. Teach. Res., vol. 7, no. July, pp. 39-64, 2019.

[27] E. Einum, "Involvement with response technology as student-centring of language teaching: Upper-secondary student and teacher experiences," Nord. J. Digit. Lit., vol. 14, no. 1-2, pp. 6-22, 2020. https://doi.org/10.18261/issn.1891-943x-2019-01-02-02

[28] S. McQuiggan, L. Kosturko, J. McQuiggan, and J. Sabourin, Mobile learning: A handbook for developers educators, and learners. New Jersey: John Wiley \& Sons, Inc, 2015. https://doi.org/10.1002/9781118938942

[29] M. F. Amir, N. Ariyanti, N. Anwar, E. Valentino, and D. S. N. Afifah, "Augmented Reality Mobile Learning System : Study to Improve PSTs' Understanding of Mathematical Development," Int. J. Interact. Mob. Technol., vol. 14, no. 9, pp. 239-247, 2020. https://doi.org/10.3991/ijim.v14i09.12909

[30] E. Scarratt and J. Davison, The media teacher's handbook, 1st ed. Oxon: Routledge, 2012.

[31] N. Bergdahl, U. Fors, P. Hernwall, and O. Knutsson, "The use of learning technologies and student engagement in learning activities," Nord. J. Digit. Lit., vol. 13, no. 2, pp. 113-130, 2018. https://doi.org/10.18261/issn.1891-943x-2018-02-04

[32] R. B. Johnson and L. Christenses, Educational research: Qualitative, quantitative, and mixed approaches, 5th ed. Los Angeles: Sage Publication, 2014.

[33] Sugiyono, Metode penelitian dan pengembangan reseach and development: untuk bidang pendidikan, manajemen, sosial, dan teknik. Bandung: Alfabeta, 2015.

[34] A. J. Nitko and S. M. Brookhart, Educational Assessment of Student, 5th ed. New Jersey: Pearson Merrill Prentice Hall, 2007.

[35] K. Houston, How to think like a mathematician: A companion to undergraduate mathematics. New York: Cambridge University Press, 2009. 
[36] C. R. Reynolds, R. B. Livingston, and V. Wilson, Measurement and assessment in teaching, 2nd Editio. London: Pearson, 2009.

[37] P. Bundu, Penilaian keterampilan proses dan sikap Ilmiah dalam pembelajaran sains. Jakarta: Departemen Pendidikan Nasional, 2006.

[38] A. De Zeeuw, T. Craig, and H. S. You, "Assessing conceptual understanding in mathematics," Proc. - Front. Educ. Conf. FIE, no. October 2013, pp. 742-744, 2013.

[39] D. J. Brahier, Teaching Secondary and Middle School Mathematics, 5th ed. New York: Routledge, 2016.

[40] S. Mccann, "Higher order m-learning: Critical thinking in mobile learning," ModSim World 2015, no. 028, pp. 1-11, 2015.

[41] H. Uzunboylu, N. Cavus, and E. Ercag, "Using mobile learning to increase environmental awareness," Comput. Educ., vol. 52, no. 2, pp. 381-389, 2009. https://doi.org/10.1016/ j.compedu.2008.09.008

[42] A. Holzer and J. Ondrus, "Mobile app development: Native or web?," Temat. Informatics, vol. 23, no. 1, pp. 22-31, 2011.

[43] R. Zheng and B. Zhou, "Recency effect on problem solving in interactive multimedia learning," Educ. Technol. Soc., vol. 9, no. 2, pp. 107-118, 2006.

[44] K. Kereluik, P. Mishra, C. Fahnoe, and L. Terry, "What knowledge is of most worth: Teacher knowledge for 21st century learning," J. Digit. Learn. Teach. Educ., vol. 29, no. 4, pp. 127-140, 2013. https://doi.org/10.1080/21532974.2013.10784716

[45] B. Hergenhahn and M. H. Olson, An introduction to theories of learning, 6th ed. New Jersey: Prentice Hall, 2001.

[46] S. Suryatin and S. Sugiman, "Comic book for improving the elementary school students' mathematical problem solving skills and self-confidence," J. Prima Edukasia, vol. 7, no. 1, pp. 58-72, 2019. https://doi.org/10.21831/jpe.v7i1.10747

[47] A. Fettig, T. R. Schultz, and M. M. Ostrosky, "Storybooks and beyond: Teaching problem solving skills in early childhood classrooms," Young Except. Child., vol. 19, no. 3, pp. 1831, 2016. https://doi.org/10.1177/1096250615576803

[48] J. A. Braus and D. Wood, Environmental education in the schools: Creating a program that works. Washington D.C.: Peace Corps, 1993.

[49] B. Csapó and J. Funke, The nature of problem solving. Using research to inspire 21st century learning. Paris: OECD Publishing, 2017. https://doi.org/10.1787/9789264273955$\underline{\text { en }}$

[50] C. Huck, S. Hepler, and J. Hickman, Children's literature in the elementary school, 4th ed. New York: Holt, Rinehart, \& Winston Inc., 1987.

[51] D. I. Matulka, A picture book primer: Understanding and using picture books, vol. 48, no. 4. Westport: Greenwood Publishing Group Inc, 2008.

[52] A. S. Sadiman, Media Pendidikan: Pengertian, Pengembangan dan Pemanfaatannya. Jakarta: PT. Raja Grafindo Persada, 2009.

[53] R. E. Mayer, The cambridge handbook of multimedia learning, Second. New York: Cambrdige University Press, 2014.

[54] W. M. Anderson and J. E. Lawrence, Integrating music into the elementary classroom, 9th ed. Boston: Cengage Learning, 2013.

[55] D. Churchill, J. Lu, T. K. F. Chiu, and B. Fox, Mobile learning design: Theories and application, vol. 63, no. 11. New York: Springer, 2016.

[56] J. Keengwe, G. Schnellert, and D. Jonas, "Mobile phones in education: Challenges and opportunities for learning," Educ. Inf. Technol., vol. 19, no. 2, pp. 441-450, 2014. https://doi.org/10.1007/s10639-012-9235-7 
[57] Y. T. C. Yang, "Building virtual cities, inspiring intelligent citizens: Digital games for developing students' problem solving and learning motivation," Comput. Educ., vol. 59, no. 2, pp. 365-377, 2012. https://doi.org/10.1016/j.compedu.2012.01.012

[58] K. Manassis, Problem solving in child and adolescent psychotherapy: A skills-based, collaborative approach. New York: The Guilford Press, 2012.

\section{$7 \quad$ Authors}

Muhammad Nur Wangid is a lecturer with 26 years of experience, associate professor in the field of educational psychology. Areas of research interest and publications are related to educational psychology, especially self-regulated learning, academic anxiety, school burnout. Recently his research interests have been linked to developments in information technology, such as augmented reality, blended learning, digital learning, and so on. He has more than 12 years of experience as an academics in postgraduate, and successfully supervised five PhD students. He presently supervises 15 Master \& PhD students, and has examined Master \& PhD Theses. He has been the head of the Postgraduate Primary Education Study Program at Yogyakarta State University Indonesia since 2013. He is the head of the board of directors of the Indonesian Primary Education Lecturer Association. He is also the editor in chief of the Prima Edukasia Journal.

Chandra Adhi Putra is a student of primary education at the Yogyakarta state university postgraduate program and also a teacher with 5 years of experience in elementary school. The areas of interest in research and publication are related to primary education, especially in terms of media innovation and learning. Mostly,his research interest related to the use of information technology in learning activity such as digital technology. Nowadays, he is a civil servant in Yogyakarta's city as an educational practitioner

Hendra Erik Rudyanto is a lecturer in the education department of elementary school teachers at Universitas PGRI Madiun. Research topics are often used are mathematics education especially in elementary school, such as elementry student's creative thinking ability, ethnomathematics learning in elementary school, etc

Article submitted 2021-02-14. Resubmitted 2021-03-14. Final acceptance 2021-03-17. Final version published as submitted by the authors. 